\title{
The Compatibility between the Quran and Modern Science: A Comparative Study among Malaysian
}

\author{
Mohd Arip Kasmo ${ }^{1}$, Abur Hamdi Usman ${ }^{2}$, Hamdzun Haron ${ }^{1}$, Abdul Salam Yusuf ${ }^{1}$, Fazilah Idris ${ }^{1}$, Nasruddin \\ Yunos ${ }^{1} \&$ Hasanah Abd Khafidz. ${ }^{1}$ \\ ${ }^{1}$ Centre for General Studies, The National University of Malaysia, Malaysia \\ ${ }^{2}$ Institute of Islam Hadhari, The National University of Malaysia, Malaysia \\ Correspondence: Abur Hamdi Usman, Institute of Islam Hadhari, The National University of Malaysia, 43600, \\ Bangi, Selangor, Malaysia. Tel: 60-16-690-5082. E-mail: aburhamdiusman@yahoo.com
}

Received: December 2, 2014 Accepted: January 20, 2015 Online Published: April 20, 2015

doi:10.5539/ass.v11n10p299 URL: http://dx.doi.org/10.5539/ass.v11n10p299

\begin{abstract}
The paper reports a study which was conducted among 644 respondents from the age of 20 to the age of 55 in Malaysia. The respondents, male and female were obtained randomly throughout the country, from different ethnic and religious backgrounds. The respondents were given booklet of questionnaire containing statements about the relation between the Quran and science. The statements were provided with responses in the form of Likert scale ranging from 1. (Strongly disagree), 2. (Disagree), 3. (Not sure), 4. (Agree), and 5. (Strongly agree). The data was analysed to obtain the mean, percentages, and the difference of means were tested using the t-test and one-Way ANOVA. The results of the study show that $66.9 \%$ of the respondents accepted the statement that the Quran is compatible with modern science. $12.6 \%$ rejected the statement and $20.5 \%$ was not sure. There were difference of means of the responses of the respondents based on their religion and the difference of mean was significant.
\end{abstract}

Keywords: perception, Quran, science, compatibility, Malaysia

\section{Introduction}

The topics on the relation between the Quran and science are being discussed worldwide. The Muslim League holds biennial conference on the scientific miracle of the Quran, inviting scientists and scholars from all over the world to participate. Many books have been written on the subject of the Quran and science highlighting the compatibility between the Quran and science (Khan, 2000). Many Muslim scholars and scientists such as Naggar (2003), the Egyptian geologist wrote many books on the relation between the Quran and science among which is about geology in the Quran.

The knowledge on the relation between the Quran and science may be well disseminated to the people in Malaysia. Since the Quran is believed by the Muslim to be the words of god, any contradiction between the Quran and science could be a fatal blow to the religion, and it could strengthened the belief if it is proven otherwise. Science is more trusted than religion in the Western countries, compared to the others and religion in the West has been weakened by the advance in science (Ferngren et al., 2000).

In Malaysia, the science curriculum was heavily influenced by the science curriculum from the British colonial power. The science curriculum in Malaysia evolved according to these phases i.e. in 1961 where the education Act was enacted, science was based on the Cambridge Examination Syllabus. In 1963, after the formation of Malaysia, science curriculum evolved further when it used the British Science Curriculum. In 1969, the science curriculum for the lower secondary school was adapted from the Scottish Integrated Science Project. In 1972 , Modern Chemistry, Modern Biology and Modern Physics were adopted from the British Nuffield Science. In 1974 Modern Science was adopted from the Nuffield British Nuffield Science but it started to be indigenous and in 1979, the implementation of the education policy was reviewed. Therefore the elements of the theory of human evolution crept into the Malaysian society from the British science curriculum which was highly biased to the theory of evolution (Jones \& Reiss, 2007). The biology subject which was taught in the Malaysian schools before the 1980 included the theory of evolution which was regarded by the conservative Muslims in Malaysia to contradict religious teachings, whereas the Quran states that human came from Adam which was the origin of all 
mankind. Thus many Muslim viewed that science contradicted the Quran and many parents shunned science course. If the people still believe that science contradicts the Quran then it is difficult to instil the love for science among the people and if they believe that science does not contradicts the Quran and is strongly linked to their belief, then it could help to promote the love for science among the people.

Therefore this study was carried out with the aims of mapping the perception of the people toward the relation between the Quran and modern science. Do people see any relationship between the Quran and science or otherwise?

\section{Literature Review}

The issue on the relation between the Quran and modern science was initially, according to certain account promoted by Bucaille (2002), the French surgeon who wrote the book The Bible, the Quran and Modern Science. Bucaille (2002) was the first Western writer who indulged in this issue, although other earlier Muslim writers have written books on the issue well before Bucaille. Muslim writers such as Sardar dubbed the act of proving the truth of the Quran by comparing the verses of the Quran with science as Bucaillism because it was assumed that Bucaille was the first person to indulge in using science to prove the truth of the Quran. However Bucaille was not the first person to deal with the Quran and science. The $12^{\text {th }}$ century Qur'an commentator, for example Fakhr al-Din al-Razi used the scientific knowledge at his time to illuminate his exegesis of the Quran (Guessoum, 2010). Muhamad Abduh, the nineteenth century Muslim scholar from Egypt, who wrote the Quranic exegesis al-Manar interpreted various verses of the Quran through the eye of science. For example he defended the theory of evolution in which he said natural selection was a devise used by God (Sedgwick, 2014).

At present there are many books written on the issue on the relation between the Quran and science among which are written by Yahya (2002), Soliman (1985), Tawfik (2008), Awadalla (2004), Naqvi (2012) and many others. Since there are more than 750 verses of the Quran which describe the universe and the nature of the universes any commentary of the Quran cannot get away from commenting the verses of the Quran without commenting them from the scientific point of views. In the field of embryology, in which the Quran in many verses talk about, Moore, et al. (1991) emphasised the strong relation between the Quran and embryology. Moore who is currently an emeritus professor at the faculty of surgery at the University of Toronto, wrote several books highlighting the strong relation between the Quran and embryology. The work of Bucaille, The Bible, the Quran and Modern science in 2002, and what is the Origin of Man in 2005 were translated in the Malay language. The information on the relation between the Quran and science shaped the general opinion of the people toward the Quran and science.

Many exegesis of the Quran discuss the verses of the Quran in the light of science have been written before. Since there were no accurate scientific knowledge during the time when the popular exegesis of the Quran at that time, it was the practice to interpret the verses according to the Arabic grammar. Some of the exegesis of the Quran, especially the exegesis of the verses which dealt with the nature of the universe, incorporated non-Islamic myths which made their way into the exegesis of the Quran when the non-Muslims embraced Islam (Ibn Khaldun, 1969).

The Muslim during that time often asked the newly converted people especially about the creation of man and the universe which were wrong scientifically, because myth was based on stories while science is based on research. One example of the verse of the Quran, chapter 71 verse 19 "And Allah has made the earth for you as a bed spreading". The verse was interpreted to be flat (Shihab, 2007).The interpretation of the verse which says the earth was flat is found in the exegesis of the Quran. The exegesis of the Quran says that the earth was flat because it was the prevalent idea at the time (Naik \& Fahim, 2014). Beside the flat earth concept, which made its way into the exegesis of the Quran, another Quranic verse which many people like to refer and some even claimed that this verse showed that the Quran is not compatible with science is the chapter 36, verse 38 "And the sun run on it course on appointed time". Although this verse does not refer to the sun rotating around the sun, some people believe that the verse is about the sun rotates around the earth, one such person is Taslima Nasreen, the Bangladeshi writer who has significant number of followers (Note 1).

As science and technology advance, observations can be made accurately and the universe and the nature of the universe can be more accurately explained, for example by using the WMAPs telescope, researchers could understand the structure of the universe better than before (Martinez, 2009). By using the Hubble telescope, researchers could explain the origin of the universe which started from the instant which is called the Big Bang (Bortz, 2013). By using the deep sea probe and submarines, researchers could explain the deep sea phenomena including the internal waves (Heikinian, 2014). The halocline phenomena of the sea (Nichols \& Williams, 2009), by using the fMRI researchers could scan the frontal lobe of the brain (Reynolds \& Horton, 2012). With the new 
discoveries, the verses of the Quran which relate the nature of the universe or part of the universe can be better understood. The new discoveries affirmed the verses of the Quran which describe part of the universe. One such verse is about the origin of the universe and the aquatic origin of living organism (Chapter 21, verse 30). There are however opposing idea about the relationship between the Quran and science. Sardar (1989) for example said that science changes along the time while the Quran does not change, and the Quran is priori true, therefore he rejected the idea of proving the truth of the Quran with science. Those who supported the idea of the compatibility between the Quran and modern science emphasised that the conformity is between the Quran and the established facts of science. Sardar (1989), and Hoodbhoy (1991), rejected the idea of the relationship between the Quran and science on the ground that science changes while the Quran does not change. Recent scientific truth changes all the time, but the elements of science do not; but there are further additions, but what is there now will not change (Jagger, 2010). The assumption that by proving the truth with science will be dangerous step because if scientific truth changes, would the Quran then be considered to be invalid?

\section{Method of the Study}

The study was conducted on 644 respondents, males and females from the age of 20 to 55 years, obtained randomly from all over the country. Every respondent was given a questionnaire containing statements on the issue of the relation between revelations and science. Each statement was provided with five choices of responses according the Likert scale i.e. 1. Strongly disagree, 2. Disagree, 3. Not sure, 4. Agree, and 5.Strongly agree. Likert scale was used as the instrument for this study because it is reliable instrument.

According to Kothari (2011), the Likert type scale has some advantages. First, it is relatively easy to construct. Second, it is considered more reliable because under it, respondents answer each statement included in the instrument. Third, each statement is given an empirical test for discriminating ability. Fourth, it can be easily used in respondents cantered and stimulus cantered studies. Fifth, it takes less time to construct. Hence the limitation of the Likert type scale is that although it can be used to examine whether respondents are more or less favourable to certain topic, but it cannot be used to know how much more or less they are. There is no basis to belief that the five responses are equally spaced. The interval between strongly agree and agree many not be equal to the interval between 'agree' and 'not sure'. Nevertheless, the Likert type scale is considered most useful, because it enable researcher to compare respondents' score with a distribution of scores from some well-defined group. The responses to the statement "The Quran is compatible with Science" was analysed by the Statistical Package for the Social Sciences (SPSS) to obtain the mean responses, the percentages of the responses.

\subsection{Data Analysis}

The first analysis was to obtain the mean response of all the respondents. The result of the analysis is shown in Table 1.

Table 1. The mean response of all the respondents

\begin{tabular}{llllll}
\hline & $\mathrm{N}$ & Minimum & Maximum & Mean & Std. Deviation \\
\hline s14 & 644 & 1.00 & 5.00 & 4.0062 & 1.18175 \\
Valid N & 644 & & & & \\
\hline
\end{tabular}

Table 1 show that the mean response is 4.0062 . The mean is close to 4 , which indicates that the respondent agree with the statement that there is no contradiction between the Quran and science.

The next analysis is to obtain the percentages of the responses for all of the respondents. The result of the analysis is shown in Table 2 .

Table 2. The percentages of the response of all the respondents

\begin{tabular}{lllll}
\hline & Frequency & Percent & Valid Percent & Cumulative Percent \\
\hline Strongly disagree & 24 & 1.9 & 3.7 & 3.7 \\
Disagree & 57 & 4.4 & 8.9 & 12.6 \\
Not sure & 132 & 10.2 & 20.5 & 33.1 \\
Agree & 109 & 8.4 & 16.9 & 50.0 \\
Strongly agree & 322 & 25.0 & 50.0 & 100.0 \\
\hline
\end{tabular}


Table 2 shows the percentages of the responses for all the respondents. The percentage of the respondents who strongly disagree with the statement that there is no contradiction between the Quran and modern science was $3.7 \%$, the percentage of the respondents who disagree was $8.9 \%$, the percentage of the respondents who was not sure was $20.5 \%$, the percentage of the respondents who agree was $16.9 \%$ and the percentage of the respondents who strongly agree with the statement was $50.0 \%$.Based on the percentages, the total percentage of the respondents who accepted that the statement that there is no contradiction between the Quran and modern science is $66.9 \%$, and those who rejected it was $12.6 \%$. Hence, the percentage of the responses is plotted to form a line curve as shown in Figure 1.

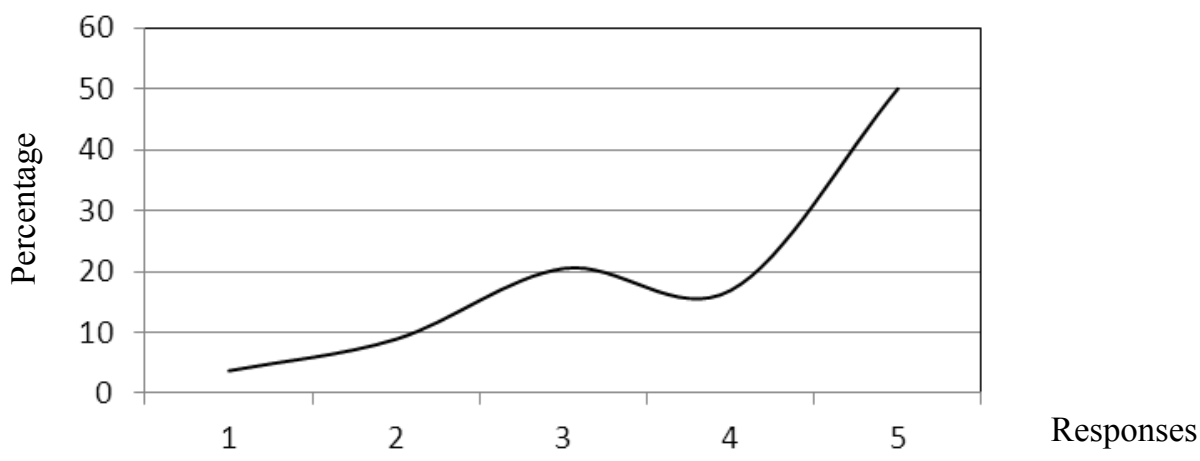

Figure 1. The line graph for the percentage of the responses of all the respondents

Figure 1 shows that the percentage of the responses increases from 1 (strongly disagree) to 5 (strongly agree). Although the line is not a straight, it can be seen that the percentages of the responses are increasing'. Furthermore, the next analysis was to obtain the mean according to the age group. The result of the analysis is shown in Table 3.

Table 3. The mean responses according to the age group of the respondents

\begin{tabular}{llll}
\hline Age group & Mean & $\mathrm{N}$ & Std. Deviation \\
\hline $20-30$ & 4.0638 & 470 & 1.15724 \\
$31-55$ & 3.8643 & 140 & 1.24201 \\
$>55$ & 3.7500 & 28 & 1.23603 \\
\hline
\end{tabular}

Table 3 shows the mean response of the respondents according to the age groups. The mean responses is 4.0638 for the age group between 20-30 years old, 3.8643 for the age group between 31-55 years old, and 3.7500 for the age group above 55 years old. Hence, the means responses of the respondents according to the age group are plotted to form a line graph as shown in Figure 2.

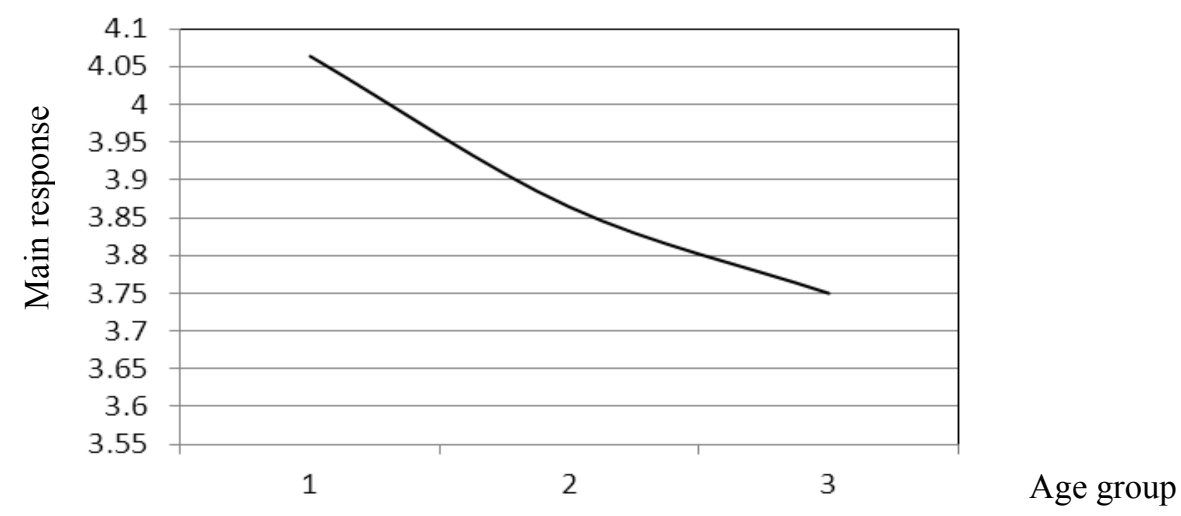

Figure 2. The line graph for the mean response according to the age group 
Figure 2 shows that the mean responses become smaller according to the age of the group, meaning the older you are the stronger the belief that there is no contradiction between the Quran and science. In addition, the next analysis was to see if the mean response were significantly different from each other. For the purpose, one way ANOVA test was conducted and the result is shown in Table 4.

Table 4. The one-way ANOVA analysis between the means of the response according to the age group

\begin{tabular}{llllll}
\hline & Sum of Squares & df & Mean Square & F & Sig. \\
\hline Between Groups & 6.218 & 2 & 3.109 & 2.234 & .108 \\
Within Groups & 883.757 & 635 & 1.392 & & \\
\hline
\end{tabular}

Table 4 shows the $\mathrm{p}$ value is 0.108 , and the value is bigger than the critical value of 0.05 . This can be interpreted that the mean difference between the age group is not significant.

The next analysis was to obtain the percentages of the responses based on the religion of the respondents. the results of the analysis is shown in Table 5.

Table 5. The percentages of the responses of the respondents based on the religion

\begin{tabular}{lllllllll}
\hline & Islam & & \multicolumn{2}{l}{ Christianity } & \multicolumn{2}{l}{ Buddhism } & \multicolumn{2}{l}{ Hinduism } \\
\hline Strongly disagreed & 3 & 0.7 & 5 & 8.5 & 10 & 11.1 & 6 & 12.5 \\
Disagree & 16 & 3.6 & 16 & 27.1 & 16 & 17.8 & 8 & 16.7 \\
Not sure & 37 & 8.4 & 25 & 42.4 & 43 & 47.8 & 25 & 52.1 \\
Agree & 80 & 18.1 & 8 & 13.6 & 14 & 15.6 & 7 & 12.6 \\
Strongly agree & 307 & 69.6 & 5 & 8.5 & 7 & 7.8 & 2 & 4.4 \\
& 443 & 100 & 59 & 100 & 90 & 100 & 48 & 100 \\
\hline
\end{tabular}

Table 5 shows the percentages of the response based on the religion of the respondents. The percentages of the responses of the respondents whose religion is Islam was $87.7 \%$ acceptance (Agree and strongly agree), the percentage of the response of the respondents whose religion is Christianity was $21.15 \%$, the percentage of the response for the respondents whose religion is Buddhism was $23.45 \%$, and the percentage of the response of the respondents whose religion is Hinduism was $17 \%$. Hence, to see clearer picture of the percentages of the response, the percentages were plotted to form line graph, as shown in Figure 3.

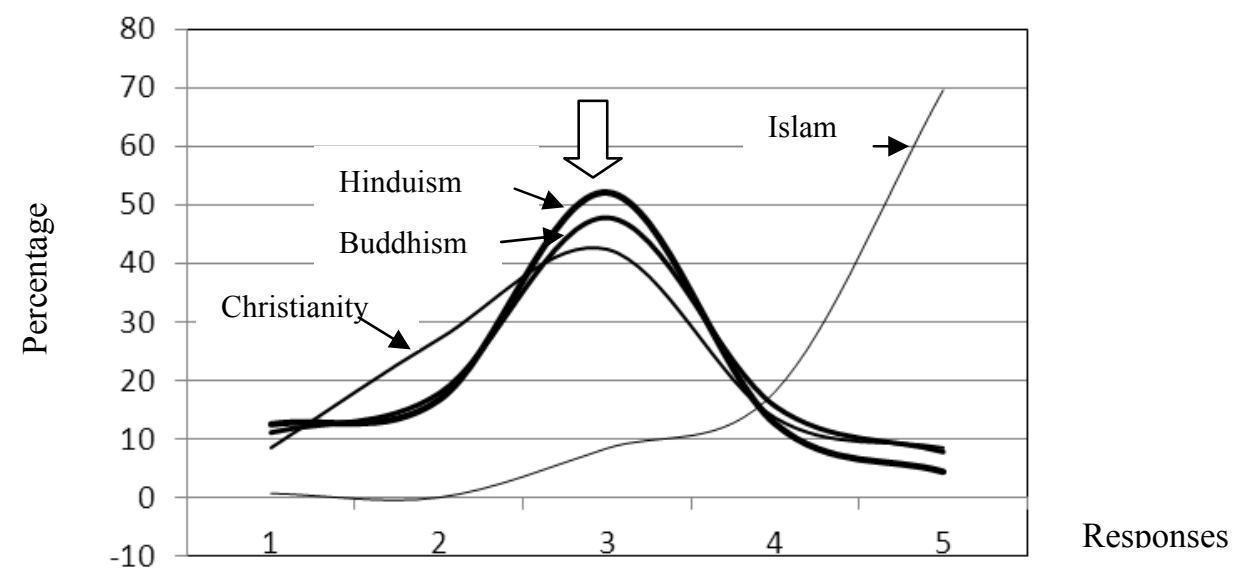

Figure 3. The line graph for the percentages of the responses of the respondents based on the religion

Figure 3 shows different curves of the percentages of the responses of the respondents based on the religion of the respondents. The graph shows that the percentages of the responses of the non-Muslim are concentrated at the centre i.e. 3 which is "not sure". 
Furthermore, the next analysis is to obtain the mean of the respondents based on their religion. The result of the analysis is shown in Table 6.

Table 6. The mean responses of the respondents according to their religion

\begin{tabular}{llll}
\hline Religion & Mean & $\mathrm{N}$ & Std. Deviation \\
\hline Islam & 4.5169 & 443 & .84637 \\
Christianity & 2.8644 & 59 & 1.04151 \\
Buddhism & 2.9111 & 90 & 1.04553 \\
Hinduism & 2.8125 & 48 & .98188 \\
\hline
\end{tabular}

Table 6 shows that the mean response of the Muslim respondents is 4.5169, the Buddhists respondents is 2.9111, the Christian respondents is 2.8644 and the Hindu respondents is 2.8125 . The analysis shows that there is difference of means. Hence, to know whether the difference of means is significant or not, a one-way ANOVA test was carried out and the result of the test is shown in Table 7.

Table 7. The one-way ANOVA test between the mean responses of the respondents based on their religion

\begin{tabular}{llllll}
\hline & Sum of Squares & $\mathrm{df}$ & Mean Square & $\mathrm{F}$ & Sig. \\
\hline Between Groups & 374.346 & 5 & 74.869 & 91.252 & .000 \\
Within Groups & 522.640 & 637 & .820 & & \\
\hline
\end{tabular}

Table 7 indicates that the $p$ value is 0.000 and the value is less than the critical value of 0.05 . Therefore, the mean difference between the respondents of different religions is significant.

\section{Discussion}

The study shows that $66.9 \%$ (combination of response 4 and 5) of the respondents accepted the statement that the Quran is compatible with science while $12.6 \%$ (combination of response 1 and 2) reject the statement (see Table 2) and $20.5 \%$ was not sure. The findings thus showed that $66.9 \%$ of the respondents accepted that the Quran is compatible with science. The mean response of all the respondents is 4.006 (see Table 1). This means that generally the respondents accepted the statement that the Quran is compatible with science. Most of the respondents who accepted the statement were the Muslim respondents the percentage of the Muslim respondents who accepted the statement (combination of response 4 and 5) is $87.7 \%$, those who rejected the statement is $4.3 \%$ (see Table 5). This indicates that $87.7 \%$ of the Muslim respondents accept that the Quran is compatible with science. The findings have shown that the Muslims in Malaysia have already changed their view on the relation between the Quran and science. The percentage of the respondents who rejected the statement is small. The Muslims respondents accepted the statement that the Quran is compatible with science because there are a lot of information about the relation between the Quran and science. There were talks on the television and radio on this topic which were aimed at disseminating the information on the relation between the Quran and science. There are also books and magazines in the markets dealing on the issue.

The results of the study has also indicated that the majority of the non-Muslims respondents chose to be neutral on this issue, the non-Muslim respondents were mostly neutral i.e. response number 3 (see Figure 3). The mean response for all the non-Muslim respondents fell slightly below 3, indicating rejection of the statement. In term of the percentage of the acceptance, there was some percentage who accepted the statement (see Table 5). The response of the non-Muslim to the statement is understandable since they do not belong to the Muslim faith; it is hard for them to accept. However, still $22.1 \%$ of the Christian respondents accepted the statement, $23.4 \%$ of the Buddhists respondents accepted the statement, and 17\% of the Hindu respondents accepted the statement (see Table 5). The non-Muslim respondents may have accepted the statement that the Quran is compatible with science because they are also exposed to the information from the mass media and prints materials.

The consequences of the belief that the Quran is compatible with science will enhance the Muslim students to study sciences even among the students of the traditional religious schools which rejected the study of science before because they believed that the Quran is not compatible with science. 


\section{References}

Awadalla, A. (2004). The Prophecy and the Warnings Shines Through the Mystifying Codes of the Holy Quran. St Victoria, Canada: Trafford Publishing.

Bortz, F. (2013). The Big Bang Theory: Edwin Hubble and the Origins of the Universe. New York: The Rosen Publishing Group.

Bucaille, M. (2002). The Bible, the Qur'an and Science: The Holy Scriptures Examined in the Light of Modern Knowledge. Islamic Books Publisher.

Bucaille, M. (2005). What is the origin of Man. Islamic Books Publisher.

Daniel, Z. A. (2006). Perubatan Islam dan bukti sains moden (Islamic medicine and the proofs of modern science) (Vol. 13). Kuala Lumpur: PTS Millennia.

Ferngren, G. B. et al. (2000). The History of Science and Religion in the Western Tradition: An Encyclopaedia. New York: Garland Publishing.

Guessoum, N. (2010). Islam's Quantum Question: Reconciling Muslim Tradition and Modern Science. London: I.B. Tauris.

Hekinian, R. (2014). Sea Floor Exploration: Scientific Adventures Diving into the Abyss. New York: Springer Science \& Business Media. http://dx.doi.org/10.1007/978-3-319-03203-0

Hoodhboy, P. (1991). Islam and Science: Religious Orthodoxy and the Battle for Rationality. New York: Zed Books.

Ibn Khaldun. (1969). The Muqaddimah: An introduction to history. Princeton: Princeton University Press.

Jagger, J. (2010). Science and the Religious Right: What Americans Should Know about Both? Bloomington: iUniverse.

Jones, L. S., \& Reiss M. J. (2007). Teaching about Scientific Origins: Taking Account of Creationism. New York: Peter Lang.

Khan, F. (2000). God Created the Universe with the Purpose to Serve Humankind. Peshawar: Khyber Mail.

Kothari, C. R. (2011). Research Methodology: Methods and Techniques. Delhi: New Age International.

Martinez, W. I. (2009). Data Analysis in Cosmology. Valencia, Spain: Springer Science \& Business. http://dx.doi. org/10.1007/978-3-540-44767-2

Moore, K. L. et al. (1991). Qur'an and Modern Science: Correlation Studies. Bridgeview, USA: Islamic Academy for Scientific Research.

Naggar, Z. R. (2003). The geological concept of mountains in the Qur'an. Cairo: Al-Falah foundation for Translation.

Naik, Z., \& Fahim, F. (2014). The Qur'an \& Modern Science: Compatible or Incompatible? Charleston: Create Space Independent Publishing.

Naqvi, E. (2012). The Quran: With Or Against the Bible? A Topic-by-topic Review for the Investigative Mind. Bloomington, Indiana: iUniverse LLC.

Nichols, C. R., \& Williams, R. G. (2009). Encyclopaedia of Marine Science. New York: Infobase Publishing.

Reynolds, C. R., \& Horton, A. M. (2012). Detection of Malingering during Head Injury Litigation. New York: Springer. http://dx.doi.org/10.1007/978-1-4614-0442-2

Sardar, Z. (1989). The future of Muslim civilization. London: Cromwell.

Sedgwick, M. (2014). Muhamad Abduh. London: One World Publication.

Shihab, M. Q. (2007). Membumikan Al-Quran: Fungsi dan Peran Wahyu dalam Kehidupan Masyarakat (To bring the Quran into the local taste: The role of revelation in the life of society). Bandung: Mizan.

Soliman, A. M. (1985). The scientific trends in the Quran. London: Ta Ha Publication.

Tawfik, M. (2008). The Quran \& Modern Science: Picture Illustrated Science from the Quran. Bloomington, Indiana: Author House.

Yahya, H. (2002). The Qur'an Leads the Way to Science. Singapore: Nickelodeon Books. 


\section{Note}

Note 1. See the Muslim World League Journal, Vol. 22 (1994). Mecca. Saudi Arabia: Press and Publications Department, Muslim World League.

\section{Copyrights}

Copyright for this article is retained by the author(s), with first publication rights granted to the journal.

This is an open-access article distributed under the terms and conditions of the Creative Commons Attribution license (http://creativecommons.org/licenses/by/3.0/). 